\title{
Assessment of the Vulnerability Potential for an Unconfined Aquifer in Konya Province, Turkey
}

\author{
M. Tahir Nalbantcilar \\ Batman University, Geological Engineering Department, Batman \\ Turkey
}

\section{Introduction}

Only two to three percent of total water on earth is fresh water, and groundwater constitutes a significant portion of the fresh water resources. This scars and fragile resource is under the risk of degradation in both quality and quantity in many parts of the world.

Three major activities cause large quantities of human and industrial waste disposals, and hence, pose serious threat to the groundwater resources. The first of these activities is excessive use of fertilizers, pesticides and automation in agricultural areas. The second one is unregulated discharge of natural and artificial chemical substances to the environment. Finally, excessive pumping and improper management of aquifers result in reducing the pumping potential and degrading the water quality.

In order to mitigate the influence of such detrimental effects, precise delineations of the aquifer system and of the hydrogeological setting in concern areas are of primary importance. In those areas, vulnerable to such adverse environmental problems, two types of remedies have been proposed. The first type is called the reactive approach which involves aquifer remediation after the contamination occurred. The preferred proactive approach, on the other hand, calls for taking the necessary measures before the contaminants reach the groundwater surface. The reactive method of aquifer remediation suffers from unsatisfactory results since it is impossible to obtain $100 \%$ purification.

The proactive method mainly involves identifying the pollutant source at an early stage and assessing the potential danger it poses to the ground water system. Geographic Information System (GIS) has been proven as an effective tool for this purpose. As in this research, Chitsazan and Akhtari (2009) and Awawdeh and Jaradat (2009) determined the risk of pollutants to contaminate the groundwater, with the help of GIS. In recent years the increase in the popularity of applying environmental criteria in national planning and management has provided a wide range of scientific approaches to determine the best location of hazardous wastes to be land filled (Abessi and Saeedi 2009).

This method is applied in many countries, such as Palestine (Baalousha 2006) Ethiopia (Tilahun and Merkel 2009) Tunisia (Saidi et al 2009), both to determine the suitable solid waste areas and to dispose other contaminants. For example, it is a preliminary assessment of the possible environmental impact of a proposed landfill facility for the city of Jammu City in India (Nagar and Mirza 2002). The researches on aquifer vulnerability is increasing 
day by day in Turkey (Nalbantcilar et al 2009, Sener et al 2009, Pusatli et al 2001) and that shows this research area is inevitable.

This work presents the results of a study carried out for the assessment of ground water contamination due to a solid waste deposition side near Konya, Turkey. The well-known DRASTIC model (Aller et al 1987) has been employed to prepare ground water vulnerability maps in an unconfined aquifer near Konya, Turkey. This aquifer supplies most of the water needs of Konya for municipal drinking and irrigation. DRASTIC utilizes a technique of developing seven layer hydrogeological maps consisting of depth to ground water, net recharge, and soil and aquifer units, topography, influence of vadose zone and hydraulic conductivity. The overlaying DRASTIC index map indicates the vulnerability degrees at various parts of the aquifer system.

Application of the DRASTIC index map to the unconfined aquifer of Konya city indicated high degree of vulnerability to contamination at the central part of the aquifer. The vulnerability map was compatible with the distance from the waste disposal site. Finally, this work also showed that while GIS is useful for over laying the hydrogeologic setting maps the DRASTIC model is useful for aquifer preservation.

\section{Groundwater pollution in solid waste disposal area}

The solid waste disposal site of Konya stores different types of domestic, industrial, medical wastes and so on. During winter and spring, the rainwater may wash out some of these waste materials, and carry them down to ground water system as it seeps through soil and rock layers. The main contaminants are $\mathrm{Al}, \mathrm{Cr}, \mathrm{Fe}, \mathrm{Li}$, and $\mathrm{Zn}$. This study has attempted to quantify the variations/increases in concentrations of such elements in the regions' groundwater bodies. Mixing of the contaminant loaded rain water with the groundwater may result in significant reduction of the ground water quality.

\subsection{Pollution control}

In the following, we will present the results of pollution control studies in an area having been used for sewage disposal site over 35 years in Konya. This site has an area of approximately 300,000 meter square with an intake of 350,000 tonnes of garbage annually (Fig. 1). In order to monitor and characterize the ground water pollution caused by solid waste disposal site in Konya, a large number of ground water wells have been sampled from representative parts of the unconfined aquifer for a period of two years.

The main geological units or which the disposal site lays are called Sakyatan formation which is a unconfined aquifer with a significantly high permeability (Hakyemez et al 1992, Nalbantcilar 2002, Nalbantcilar and Guzel 2006, Nalbantcilar and Ozdemir 2009 and 2010).

The data having been collected over 50 years by Meteorology General Directorate indicate that this area receives 326.5 millimeter annual average precipitation. Such a rate of rainfall can wash out significant amounts of contaminating ions carrying them down to the ground water table. In order to quantify the degree of pollution, the monitoring wells were selected. This monitoring showed that they were in line with the ground water flow direction from the disposal site towards downtown Konya (Fig. 2). In situ conductivity values were measured in each of the wells, water samples were collected at specific periods and their chemical analysis was performed in the Selcuk University labs by ICP-AES. 


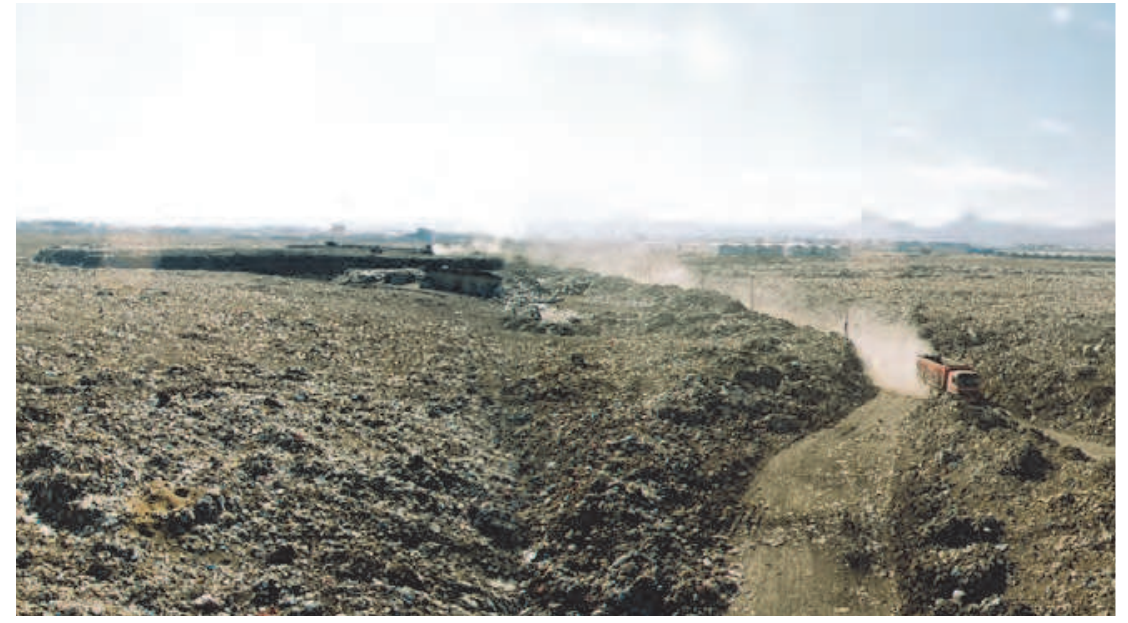

Fig. 1. A view from the solid waste area of Konya before rehabilitation.

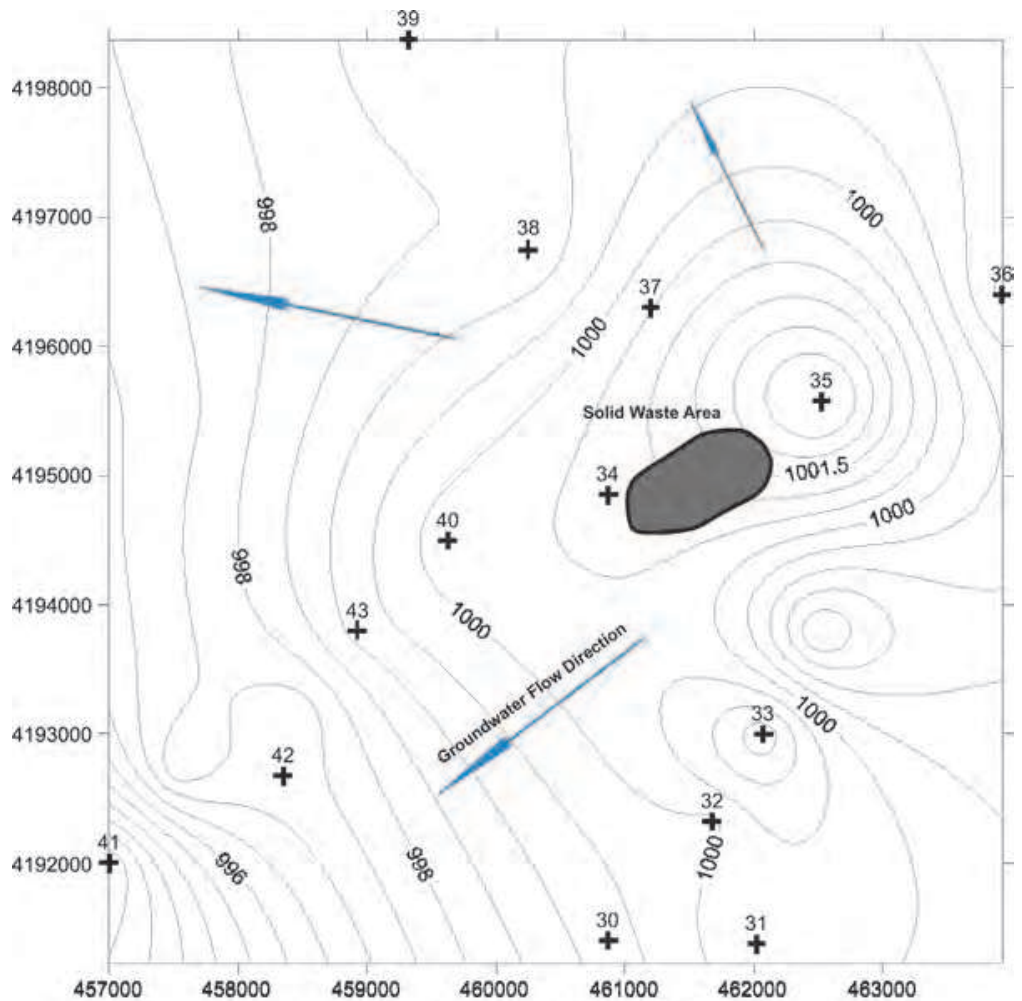

Fig. 2. Groundwater table map (in meters) and flow directions with solid waste area (Nalbantcilar and Ozdemir 2010). 

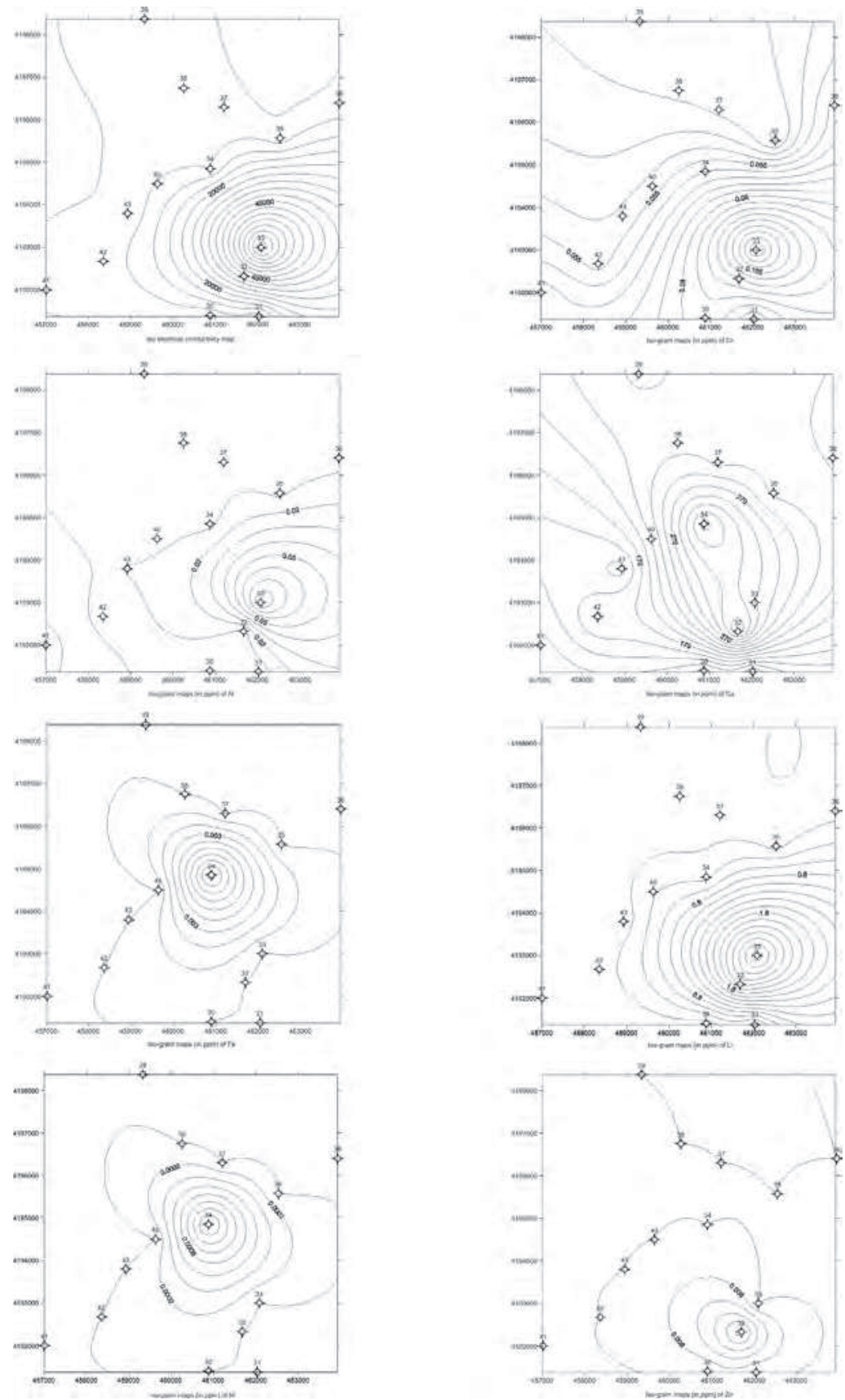

Fig. 3. Distribution maps of conductivity of the water samples and $\mathrm{Cr}, \mathrm{Al}, \mathrm{Ca}, \mathrm{Fe}, \mathrm{Li}, \mathrm{Ni}$ and Zn concentrations (mg/lt) (Nalbantcilar and Ozdemir 2010). 
The concentration maps concluded that $\mathrm{Cr}, \mathrm{Al}, \mathrm{Li}$, and $\mathrm{Zn}$ were in high concentrations in the South Eastern part of the study area, $\mathrm{Fe}, \mathrm{Ni}$ concentrations were more pronounced in the central parts and $\mathrm{Ca}$ concentration was dominant in the Southern part. As for the specific local values, well-33 had $\mathrm{Ca}$, Li, and $\mathrm{Al}$, well-32 had $\mathrm{Zn}$, and finally well-34 had $\mathrm{Ca}, \mathrm{Fe}$, and $\mathrm{Ni}$ as their highest concentration contaminants.

Such findings lead to the conclusion that especially $\mathrm{Al}$ and $\mathrm{Zn}$ concentrations in the ground water were closest to the disposal site and declined proportionally with the distance from the site. Based on the main conductivity measurement and water sample analysis data, concentration contour maps were prepared for each of the elements (Fig. 3).

\section{Drastic method/gis and assessment of contamination}

The DRASTIC method developed by US Environmental Protection Agency (EPA) has proven to be a useful tool for assessing ground water contamination potential. The method depends on utilizing seven hydrogeologic parameters: Depth to water table, net Recharge, Aquifer media, soil media, Topography, Impact of the vadose media, and hydraulic Conductivity of aquifer. These perimeters are transferred to GIS media as separate layers. Finally at the bottom, the drastic layer is formed as an integrated summary layer (Fig. 4).

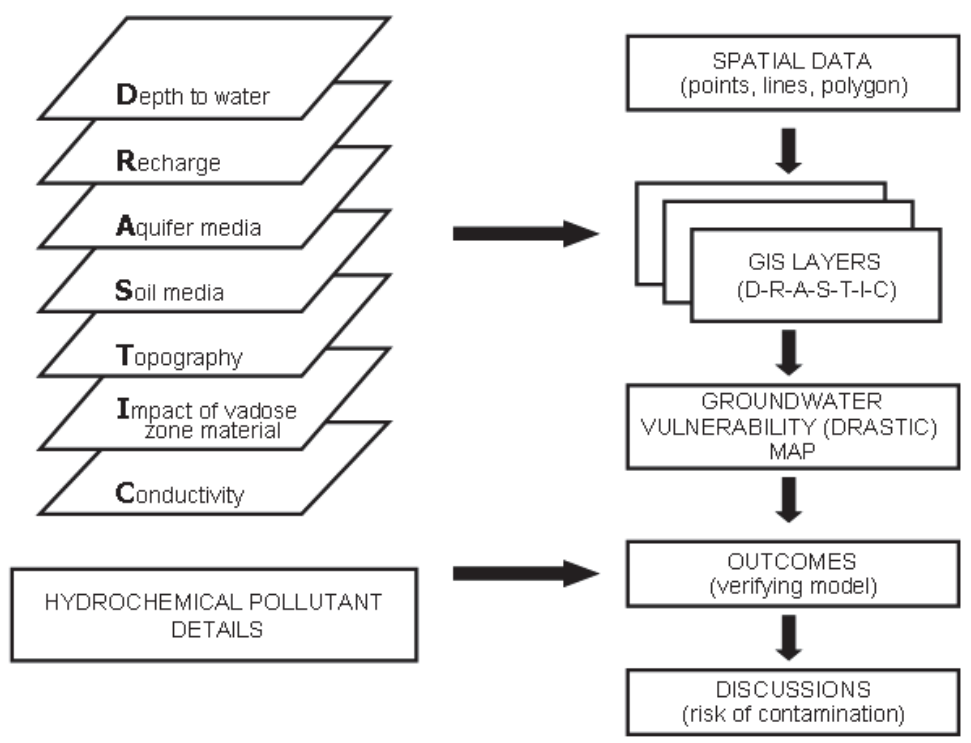

Fig. 4. Technique of DRASTIC with GIS layers (Nalbantcilar et al 2009).

DRASTIC is a numerical ranking system to assess ground water vulnerability in various hydrogeological settings. It is based on generating GIS layers for each of the seven hydrogeologic parameters and at the bottom, most layer is developed as the integrated DRASTIC layer. Each layer is assigned as a relative weight factor ranging from 1-5. The most significant factors have weights of 5 (Depth to water table and Impact of the vadose zone media), 4 (Net Recharge), 3 (Aquifer media and hydraulic conductivity), 2 (Soil media) and the least significant have weights of 1 (Topography). 
The DRASTIC layers prepared for Konya in Figure 5 show that when the unconfined aquifer falls into DRASTIC categories of 1-2, it indicates low vulnerability and at 7-8 and 9-10, it indicates high vulnerability.

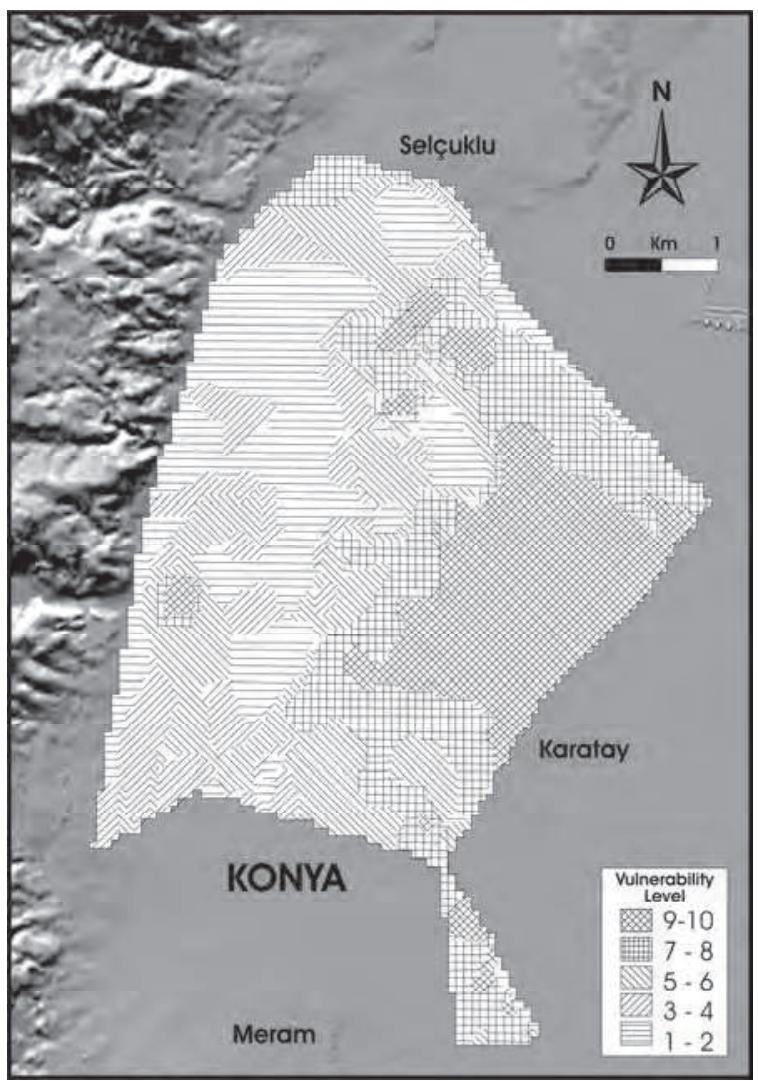

Fig. 5. The DRASTIC index map of the study area.

\section{Results and discussions}

An extensive sampling and in situ conductivity measurements of a large number of water wells have been carried out in the study area. Based on this data, the elemental concentration contour maps showed that the solid waste site has adversely influenced the ground water quality severely, contaminating the nearby zone. The contamination will get worse unless proactive precautions are undertaken. Therefore, the present situation poses serious threat to groundwater resources of Konya. The drastic map and the current city development plans with the present solid waste sites show that ground water resources are at great risk of contamination.

DRASTIC has proven to be a useful tool for evaluating vulnerability of Konya aquifers as well. Thus monitoring, an evaluation by GIS must continue in the future in this area. In addition, aquifer management techniques must be employed diligently. 


\section{References}

Abessi O. and Saeedi M., 2009, Site Selection of a Hazardous Waste Landfill Using GIS Technique and Priority Processing, a Power Plant Waste in Qazvin Province Case Example; Environmental Science, Vol. 6, No. 4, 121-134.

Aller L., Bennett T., Lehr J.H., Petty R.J., Hackett G., 1987, DRASTIC: A Standardized System for Evaluating Groundwater Pollution Potential Using Hydrogeologic Setting: US Environmental Protection Agency Report No: EPA/600/2-87/035, USA.

Awawdeh M.M. and Jaradat R.A., 2009, Evaluation of Aquifer Vulnerability to Contamination in The Yarmouk River Basin, Jordan, Based on DRASTIC Method: Arab J Geosci, DOI 10.1007/s12517-009-0074-9.

Baalousha H., 2006, Vulnerability Assessment for The Gaza Strip, Palestine Using DRASTIC: Environ Geol, 50, 405-414.

Chitsazan M. and Akhtari Y., 2009, A GIS-based DRASTIC Model for Assessing Aquifer Vulnerability in Kherran Plain, Khuzestan, Iran: Water Resour Manage, 23, 11371155.

Hakyemez H.Y., Elibol E., Umut M., Bakırhan B., Kara I., Dağıstan H., Metin T., Erdoğan N., 1992, Geology of Konya-Çumra-Akören: Report No: 9449, General Directorate of Mineral Research and Exploration (MTA), Ankara, Turkey (in Turkish).

Nagar B.B. and Mirza U.K., 2002, Hdrogeological Environmental Assessment of Sanitary Landfill Project at Jammu City, India: Electronic Green Journal, 1 (17), Article 3.

Nalbantcilar M.T., 2002, Groundwater Quality and Contamination of Konya Settlement Area: Ph D. dissertation, Selcuk University, Konya, Turkey (in Turkish).

Nalbantcilar M.T. and Guzel A., 2006, Trace Element Pollution of Drinking Water Supply of Konya, Turkey: Journal Geological Society of India, 68, 1087-1092.

Nalbantcilar M.T. and Özdemir A., 2009, Environmental Problem as Result From Chemistry of Solid Waste Area Leachate of Konya (Turkey): Taibah International Chemistry Conference, 175, Saudia Arabia.

Nalbantcilar M.T. and Özdemir A., 2010, The Effect of Konya Waste Disposal Site on Groundwater Quality: Selcuk University, Scientific Research Project, 2002/220, Konya, Turkey (in Turkish).

Nalbantcilar M.T., Guzel A. and Durduran S.S., 2009, Assessing of Groundwater Vulnerability Contamination Potential of Konya, Turkey, Using Hydrogeological Specifications and GIS: Asian Journal of Chemistry, 21/4, 2925-2934.

Pusatlı O.T., Çamur M.Z. and Yazıcıgil H., 2001, Contamination Risk Assessment for Groundwater of the K. Menderes River Basin, İzmir, Turkey: Integrated Water Resources Management, IAHS Red Book Series, 425-430.

Saidi S., Bouri S. and Dhia H.B., 2009, Groundwater Vulnerability and Risk Mapping of The Hajeb-Jelma Aquifer (Central Tunisia) Using a GIS-based DRASTIC Model: Environ Earth Sci, DOI 10.1007/s12665-009-0143-0.

Sener E., Sener S. and Davraz A., 2009, Assessment of Aquifer Vulnerabilitiy Based on GIS and DRASTIC Methods: A Case Study of The Senirkent-Uluborlu Basin, Isparta, Turkey: Hydrogeology Journal, DOI 10.1007/s10040-009-0497-0. 
Tilahun K. and Merkel B.J., 2009, Assessment of Groundwater Vulnerability to Pollution in Dire Dawa, Ethiopia Using DRASTIC: Environ Earth Sci, DOI 10.1007/s12665-0090134-1. 


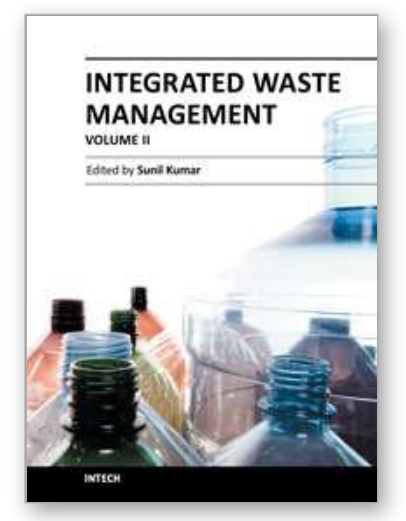

\author{
Integrated Waste Management - Volume II \\ Edited by Mr. Sunil Kumar
}

ISBN 978-953-307-447-4

Hard cover, 472 pages

Publisher InTech

Published online 23, August, 2011

Published in print edition August, 2011

This book reports mostly on institutional arrangements under policy and legal issues, composting and vermicomposting of solid waste under processing aspects, electrical and electronic waste under industrial waste category, application of GIS and LCA in waste management, and there are also several research papers relating to $\mathrm{GHG}$ emission from dumpsites.

\title{
How to reference
}

In order to correctly reference this scholarly work, feel free to copy and paste the following:

M. Tahir Nalbantcilar (2011). Assessment of the Vulnerability Potential for an Unconfined Aquifer in Konya Province, Turkey, Integrated Waste Management - Volume II, Mr. Sunil Kumar (Ed.), ISBN: 978-953-307-4474, InTech, Available from: http://www.intechopen.com/books/integrated-waste-management-volumeii/assessment-of-the-vulnerability-potential-for-an-unconfined-aquifer-in-konya-province-turkey

\section{INTECH}

open science | open minds

\author{
InTech Europe \\ University Campus STeP Ri \\ Slavka Krautzeka 83/A \\ 51000 Rijeka, Croatia \\ Phone: +385 (51) 770447 \\ Fax: +385 (51) 686166 \\ www.intechopen.com
}

\author{
InTech China \\ Unit 405, Office Block, Hotel Equatorial Shanghai \\ No.65, Yan An Road (West), Shanghai, 200040, China \\ 中国上海市延安西路65号上海国际贵都大饭店办公楼405单元 \\ Phone: +86-21-62489820 \\ Fax: +86-21-62489821
}


(C) 2011 The Author(s). Licensee IntechOpen. This chapter is distributed under the terms of the Creative Commons Attribution-NonCommercialShareAlike-3.0 License, which permits use, distribution and reproduction for non-commercial purposes, provided the original is properly cited and derivative works building on this content are distributed under the same license. 